ROBERT Z. LAWRENCE

Brookings Institution

ROBERT E. LITAN

Brookings Institution

\title{
The Protectionist Prescription: Errors in Diagnosis and Cure
}

ADVOCATES OF PROTECTION rest their case primarily on two basic premises. The first is the commonsense notion that high-wage countries, such as the United States, cannot compete with low-wage countries. If workers are paid twelve dollars an hour in America and less than two in Korea and both countries have access to world markets for capital and technology, firms located in Korea can always underprice those in the United States. If such countries engage in free trade, workers in the high-wage economy face two disastrous options: unemployment or slave-level wages.

The second is the unlevel playing field argument, which appeals to U.S. national self-interest. The real world is dominated by nationalistic economic policies. The competitive, open environment assumed by international trade economists simply does not exist. Only the United States bases its policies on the rules of the free market. Foreign governments support targeted industries with subsidies, selective procurement, and trade protection. The result is an unlevel playing field on which the ball inevitably bounces toward the U.S. goal.

For protagonists of both these positions the correct response to these problems seems clear: America should abandon the view that market forces dominate trade flows. ${ }^{1}$ It should act like other countries and manage trade to its advantage. Imports of foreign products should be

We thank Gregory I. Hume for diligent research assistance. This paper draws on our study, Saving Free Trade: A Pragmatic Approach (Brookings, 1986).

1. See, for example, John M. Culbertson, "The Folly of Free Trade," Harvard Business Review, vol. 64 (September-October 1986), pp. 122-28. 
strictly controlled with quotas until and unless wage levels and industrial policies abroad resemble those in the United States. Unless the United States protects its markets, the argument continues, the trade deficit will balloon further, and the manufacturing base will continue to shrink.

We share with the new protectionists a deep concern about America's trade deficit but firmly reject their diagnosis of America's trade problems and offer three propositions in rebuttal. First, since wage levels tend to reflect productivity levels, high-wage countries such as the United States can compete with low-wage countries because their superior productivity compensates for higher wage rates. If developing countries really had U.S. skills, technology, and capital levels, their wages would no longer be low. Second, the gains from specializing along the lines of comparative advantage are not absent simply because government trade policies worldwide are more interventionist than assumed in some versions of trade theory. Finally, while practices such as subsidies and tariffs will affect the composition of trade over the medium run, they will not affect the size of the trade balance. That is driven by a nation's spending and saving patterns. A country with investment opportunities that exceed its domestic saving will borrow from abroad and run a trade deficit even if its costs are relatively low, its home markets protected, and its exports subsidized. Conversely, a nation with high saving relative to investment will run trade surpluses even if its markets are open and its products poorly regarded. It is our contention that the recent deterioration in the U.S. trade position resulted from the decline in U.S. net national saving when the growing federal budget deficit was not matched by a corresponding increase in net private saving.

Our first objective in this article is to demonstrate the logic and empirical evidence behind each of these propositions. We then consider the effectiveness of quota protection in saving jobs, improving the trade deficit, restoring competitiveness, and preserving essential industries. We conclude by offering suggestions for dealing with both the trade deficit and the pressures for protection it spawns.

\section{Is the Trade Deficit Due to Imports from Low-Wage Countries?}

Between 1981 and 1986, the U.S. current account balance, including both goods and services, declined from a $\$ 6$ billion surplus to a deficit of 
Table 1. U.S. Trade by Selected End-Use Categories, 1981-86

Percent of total unless otherwise specified

\begin{tabular}{|c|c|c|c|c|c|c|c|}
\hline \multirow[b]{3}{*}{ Category } & \multirow{2}{*}{\multicolumn{2}{|c|}{ Exports }} & \multirow{2}{*}{\multicolumn{2}{|c|}{ Imports }} & \multicolumn{3}{|c|}{$\begin{array}{c}\text { Change in trade balance } \\
\text { (billions of dollars) }\end{array}$} \\
\hline & & & & & \multirow[b]{2}{*}{ Actual } & \multirow[b]{2}{*}{ Proportional $^{\mathrm{b}}$} & \multirow{2}{*}{$\begin{array}{c}\text { Actual } \\
\text { minus } \\
\text { proportiona }\end{array}$} \\
\hline & 1981 & 1986 & 1981 & 1986 & & & \\
\hline Capital good & 69.6 & 67.8 & 33.5 & 32.5 & -43.2 & -43.6 & 0.4 \\
\hline Automotive products & 15.6 & 19.0 & 28.7 & 33.4 & -45.8 & -38.4 & -7.4 \\
\hline Consumer goods & 14.8 & 13.2 & 37.8 & 34.1 & -44.0 & -50.8 & 6.8 \\
\hline
\end{tabular}

Sources: Data for 1981 are from U.S. Department of Commerce, International Trade Administration, United States Trade: Performance in 1985 and Outlook (Government Printing Office, 1986). Data for 1986 were provided by Lester Davis of the ITA. Figures are rounded.

a. Change in the manufactured goods trade balance between 1981 and 1986.

b. The difference between what the trade balance would have been in each category if the 1981 proportions of total imports and exports had been maintained, and the actual trade balance in 1981 .

$\$ 141$ billion. The decline in the manufactured goods trade balance over the period was almost as large- $\$ 135$ billion. Since both the low-wage and unlevel playing field arguments apply particularly to manufactured goods trade, it is instructive to examine U.S. trade performance in manufactured goods more closely.

The deterioration in the American merchandise trade balance was pervasive, across both goods and countries. As table 1 shows, the slump was uniformly and proportionately spread across capital goods (down $\$ 43.2$ billion), automotive products (down $\$ 45.8$ billion), and consumer goods (down $\$ 44.0$ billion). Similarly, as shown in table 2 , the United States lost trade position with each of its major trading partners. Indeed, not only was the increase in the U.S. deficit roughly proportional to each partner's share of the U.S. import and export shares in 1981, but the U.S. import shares of different trading partners have changed strikingly little. The largest shift between 1981 and 1986 was the 3.0 percentage point decline in the Canadian share of U.S. imports. Imports from Japan (up from 25.3 percent to 27.4 percent) and Europe (unchanged at 22.4 percent) grew roughly as fast as the rest of the U.S. market.

Competition between U.S. products and foreign products made with cheap labor is most intense in the U.S. domestic market. If low wages abroad were driving the American trade deficit, therefore, the share of imports from developing countries should have risen dramatically. But as table 2 indicates, the share of manufactured imports from developing countries in 1986 ( 25.9 percent) was about the same as the share in 1981 (25.0 percent). 
Table 2. U.S. Manufactured Goods Trade, by Region, 1981-86

Percent of total unless otherwise specified

\begin{tabular}{|c|c|c|c|c|c|c|c|}
\hline \multirow[b]{3}{*}{ Region } & \multirow{2}{*}{\multicolumn{2}{|c|}{ Exports }} & \multirow{2}{*}{\multicolumn{2}{|c|}{ Imports }} & \multicolumn{3}{|c|}{$\begin{array}{c}\text { Change in trade balance } \\
\text { (billions of dollars) }\end{array}$} \\
\hline & & & & & \multirow[b]{2}{*}{ Actual } & \multirow{2}{*}{$\begin{array}{l}\text { Propor- } \\
\text { tional }^{\mathrm{b}}\end{array}$} & \multirow{2}{*}{$\begin{array}{c}\text { Actual } \\
\text { minus } \\
\text { proportional }\end{array}$} \\
\hline & 1981 & 1986 & 1981 & 1986 & & & \\
\hline Canada & 20.2 & 24.0 & 20.2 & 17.2 & -14.4 & -30.3 & 15.9 \\
\hline Japan & 6.1 & 10.0 & 25.3 & 27.4 & -38.4 & -38.4 & 0.0 \\
\hline Europe & 23.2 & 24.0 & 22.4 & 22.4 & -32.1 & -33.5 & 1.4 \\
\hline Other developed countries & 8.8 & 8.3 & 5.6 & 5.3 & -8.3 & -8.3 & 0.0 \\
\hline Less developed countries & 40.5 & 31.6 & 25.0 & 25.9 & -54.9 & -36.9 & -18.0 \\
\hline $\begin{array}{l}\text { Asian newly industrialized } \\
\text { countries }\end{array}$ & 5.9 & 7.7 & 13.6 & 15.5 & -23.3 & -20.5 & -2.8 \\
\hline Centrally planned economies & 1.2 & 2.1 & 1.5 & 1.8 & -1.5 & -2.2 & 0.7 \\
\hline Total (billions of dollars) & 166.8 & 169.8 & 156.4 & 308.9 & -149.6 & -149.6 & 0.0 \\
\hline
\end{tabular}

Source: Same as table 1. Figures are rounded.

a. Change in the manufactured goods trade balance between 1981 and 1986.

b. The difference between what the trade balance would have been in each region if the 1981 proportions of total imports and exports had been maintained, and the actual trade balance in 1981 .

Indeed, the longer-run evidence throws even greater doubt on the cheap-wage argument, which implies an inexorable increase in the shares of imports from cheap-labor countries. In fact, U.S. imports show precisely the opposite behavior. In 1960, two-thirds of manufactured imports into the United States came from countries with income and wage levels less than half those in the United States. By 1986, the share from countries with income levels less than half those in the United States had dropped dramatically, to less than a third. In 1960, of course, Japan and many European countries had cheap labor by this definition; today they no longer do. If cheap labor really determined trade deficits, the United States should have had a much larger deficit in the 1960s, when much more of the world, by economic weight, had lower relative wages than it does today.

Finally, the progressive lowering of trade barriers between the United States and other developed countries was not associated with a leveling down of U.S. wages to those of foreign developed countries, but rather with rapid economic growth both here and abroad. Moreover, instead of permanently maintaining low wages, Europe and now Japan have wages that have converged to U.S. standards roughly in parallel with levels of productivity in all these countries. 


\section{Are Unfair Trade Practices to Blame for the Rising Trade Deficit?}

There is ample evidence that virtually all countries, including the United States, maintain at least some restrictions on imports. ${ }^{2}$ Nevertheless, restrictive trade practices are not the driving force behind the recent rise in the U.S. trade deficit. Whatever the slope of the playing field, the trading system did not prevent the United States from attaining a growing surplus in manufactured goods trade between 1973 and 1981. Non-OPEC developing countries actually bought $\$ 11.6$ billion more in manufactured goods from the United States in 1981 than the United States bought from them. ${ }^{3}$

To account for the turnaround of the overall U.S. trade deficit, foreign trade practices would uniformly and suddenly have had to change around 1981. Indeed, something close to a massive global conspiracy should have taken place. Yet protection is not much greater in the rest of the world today than it was in 1981. In fact, the Europeans have cut back on their industrial subsidies, and the Japanese market is somewhat more open. As shown in table 2, the United States sent a larger fraction of its manufactured exports to Japan in 1986 (10.0 percent) than it did in 1981 (6.1 percent). In fact, the market in which protection has recently increased the most is probably the United States. According to Bela Balassa and Carol Balassa, between 1981 and 1983 the proportion of U.S. imports covered by nontariff barriers rose rapidly and overtook the proportion of such imports in the European Community. ${ }^{4}$ Since 1981, the United States has slapped tariffs or quotas on automobiles, machine tools, motorcycles, semiconductors, and steel and has flirted with protection for shoes and wine, among other products.

2. Office of the United States Trade Representative, National Trade Estimate: 1986 Report on Foreign Trade Barriers (Government Printing Office, 1986).

3. In fact, according to estimates of the World Bank the nontariff barriers constraining U.S. imports in 1983 were actually more pervasive than the average tariffs imposed in industrial countries. Forty-three percent of U.S. imports were impaired by NTBs; the average in a sample of sixteen industrial countries was 27.1 percent. See Julio J. Nogues, Andrzez Olechowski, and L. Alan Winters, "The Extent of Nontariff Barriers to Industrial Countries' Imports," The World Bank Economic Review, vol. 1 (September 1986), pp. 181-99.

4. Bela Balassa and Carol Balassa, "Industrial Protection in the Developed Countries," World Economy, vol. 7 (June 1984), pp. 179-96. 
Although Japan continues to be frequently singled out as having the most unfair trading practices of all U.S. trading partners, it is doubtful that such policies have been a major cause of the dramatic increase in Japan's trade surplus with the United States since 1981. Table 2 indicates that the Japanese share of the deficit growth is virtually proportional to its 1981 trade share. In 1981, Japan accounted for 25.3 percent of U.S. manufactured imports and 6.1 percent of manufactured exports. Maintaining these 1981 shares in 1986 would have entailed a rise in the U.S. trade deficit with Japan of $\$ 38.4$ billion, which is precisely the rise that occurred. In short, it appears that Japan simply maintained its share of the action rather than that it dramatically shifted its behavior as the unlevel playing field argument implies.

The Japanese trade balance over the long run also indicates that the protection in the Japanese market has not created a chronic tendency toward surplus. Between 1965 and 1973, Japan's current account balance averaged 1.1 percent of gross domestic product (GDP). Between 1974 and 1984 , it averaged 0.7 percent.

The pervasiveness and speed of the decline by commodity category and trading partner also suggests that a third frequently mentioned culprit-a loss in fundamental competitiveness due to weak innovation and poor product quality -is not, in fact, a major cause of the enlarged trade deficit.

\section{The Real Culprit: The Exploding Federal Budget Deficit}

If low wages and unfair practices in other countries are not the primary causes of the extraordinary runup in the U.S. trade deficit since 1981 , then what is to blame? The pervasive character of the increase in the trade deficit suggests that something aggregative or macroeconomic is at work. ${ }^{5}$ In fact, that is precisely what has occurred. By definition, a nation's trade balance represents the difference between its total spending and production. A nation that spends more than it produces must necessarily run a trade deficit. As shown in figure 1, the United States has been in such a net spending situation since 1981. Between 1981 and 1986 , total real U.S. spending on private consumption and investment

5. The same point is made in the Economic Report of the President, 1987, pp. 98-101. 
Figure 1. Changes in National Spending and Production, United States, 1980-86

Billions of 1982 dollars

$1980=0$

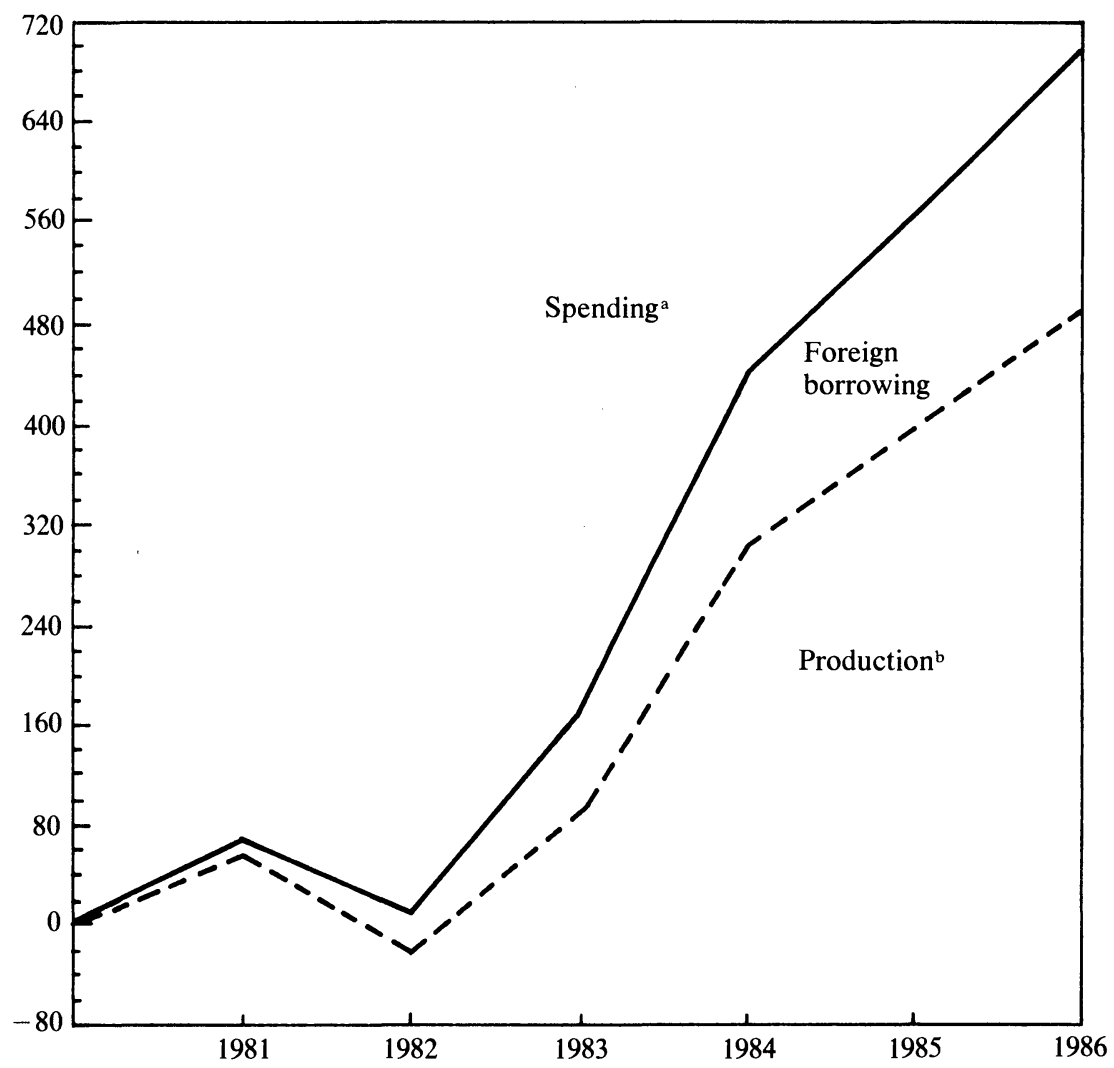

Sources: U.S. Department of Commerce, Bureau of Economic Analysis, The National Income and Product Accounts of the United States, 1929-82 Statistical Tables (Government Printing Office, 1986), and Survey of Current Business, vol. 67 (March 1987).

a. Sum of personal consumption expenditures, gross private investment, and government purchases of goods and services.

b. GNP in 1982 dollars.

and on government-provided services increased 19.6 percent, 6.4 percentage points faster than the increase in U.S. production.

One need not look far to discover what lies behind the spendingproduction imbalance. Between 1981 and 1986 the government sector (federal, state, and local combined) increased its annual borrowing about $\$ 100$ billion. Annual borrowing by the federal government alone exploded at an even faster pace, increasing from $\$ 64$ billion in 1981 to over 
$\$ 200$ billion in 1986 . The private sector failed to increase its saving to balance the government's spending splurge. In fact, net private investment ran ahead of net private saving in 1986 , contributing to the excess level of national spending.

In short, a fundamental imbalance between U.S. production and spending since 1981 has necessarily produced a mushrooming trade deficit. Correspondingly, only a reversal of this imbalance can close the gap. How the United States chooses to accomplish that objective is perhaps the most important economic policy question facing the nation in the years ahead.

\section{The Protectionist Prescription}

Advocates of quota protection for U.S. industries claim that such policies could improve the trade balance, save jobs, provide firms with an opportunity to restore their international competitiveness, and preserve essential industrial capacity. In this section we consider these rationales for protection.

\section{IMPROVING THE TRADE BALANCE}

Claims that protecting industries can reduce the trade deficit can be best evaluated by viewing the current account balance as a function of national spending behavior. If, in an economy with fully employed resources or, alternatively, a constant level of unemployment, a quota levied on imports raises spending on domestic goods, imports elsewhere must rise to meet increased demand, or else resources must be drawn from other sectors of the economy, thus reducing exports. Just as squeezing a balloon will redistribute but not reduce the total amount of air in the balloon, so, in the absence of a change in total national spending, imposing quotas will change only the composition of trade, not the overall current account balance. ${ }^{6}$

6. While a quota may restrict the quantity of particular imports sold in the United States, it need not lower the dollar value of those imports. Indeed, by raising domestic and import prices a quota could actually worsen rather than improve the trade balance expressed in current dollars. According to estimates by Clifford Winston and others, the voluntary restraint agreements on Japanese automobile exports to the United States actually raised the value of Japanese automobile sales in the United States by $\$ 3$ billion in 1984. See Clifford Winston and Associates, Blind Intersection? Policy and the Automobile Industry (Brookings, 1987), p. 65. 
To be sure, if total unemployment is allowed to vary, selective protectionist policies could raise production and income in specific sectors in the short run without reducing them in other sectors. Provided that some of the increased income is not spent, the current account balance would improve. The critical question, however, is whether the economy's total production, typically constrained by the amount of monetary growth the central bank will allow, could increase. Unless the bank accommodates a rise in domestic production, employment in industries competing with imports will simply increase at the expense of employment elsewhere. Expanded production of one product thus again entails decreased production of another.

Movements in the exchange rate provide one mechanism by which this process operates. In the short run, a quota may reduce imports, but if other factors remain unchanged, it will also increase the current account balance, strengthen the currency, and thereby make it more difficult for other sectors in the economy to compete internationally. Protecting such industries as steel and textiles, for example, will keep the dollar strong and consequently hurt export sectors such as computers and aircraft. For the medium and long term, in which the economy tends toward a given employment level, quotas are unlikely to have major effects on the trade balance unless policies are adopted to shift national spending patterns.

The current account balance equals the sum of net private saving (saving minus investment) and government saving (tax revenues minus government spending). ${ }^{7}$ The only way to improve the current account

7. This conclusion can be demonstrated from the accounting equality between the gross national product $(G N P)$ and gross national income $(G N I)$. GNP is the sum of private consumption $(C)$, private investment $(I)$, government spending $(G)$, and exports of goods and services $(X)$, minus imports of goods and services $(M)$, or

$$
G N P=C+I+G+X-M .
$$

GNI equals the sum of private consumption $(C)$, private saving $(S)$, and government taxes $(T)$, or

$$
G N I=C+S+T .
$$

Since, both valued at market prices, GNP must equal $G N I$, the two identities can be set equal to each other:

$$
C+S+T=C+I+G+X-M .
$$

After $C$ is subtracted from each side, these terms can be rearranged into a fundamental identity:

$$
(S-I)+(T-G)=X-M
$$


balance on a sustainable basis is to increase the sum of net private and government saving, either by increasing tax revenues or gross private saving or by reducing government expenditures or private investment. Quotas may have temporary effects on each of these variables but will not lead to a permanent improvement in the trade balance without permanent shifts in economywide saving and investment behavior.

\section{SAVING JOBS}

Even if monetary policy permitted total unemployment to vary, claims that quotas protecting certain sectors of the economy will increase overall domestic employment are also questionable. Protection may add to jobs within an industry, but it will also raise prices of the goods or services produced in that industry. Increased prices may lead to fewer jobs for those distributing protected goods and for workers using those goods to manufacture other products. A preliminary analysis of H.R. 1562, a textile quota bill passed by the House of Representatives in 1986, by the International Business and Economic Research Corporation, for example, estimated that while the quotas on foreign textiles would add about 71,000 jobs in the textile and apparel industries, almost as many jobs would be lost in the retail sector. ${ }^{8}$ Protection of an industry that produces intermediate goods has similar effects. By increasing domestic prices for steel, for example, quota protection undermines the competitiveness of the automobile and machinery industries-heavy users of steel.

Quotas may also take the form of provisions requiring domestic materials. These local content provisions also raise costs to consumers. As Gene Grossman has pointed out, the increase in the output of domestic components generated by domestic content requirements can be more than offset by the decrease in demand for final goods. ${ }^{9}$ Similarly, quotas can induce foreign suppliers to upgrade the quality of their products. The voluntary restraint agreements limiting imports of Japanese automobiles into the United States during the past five years were instru-

8. Laura Megna Baughman and Thomas Emrich, "Analysis of the Impact of the Textile and Apparel Trade Enforcement Act of 1985" (Washington, D.C.: International Business and Economic Research Corp., June 1985).

9. Gene M. Grossman, "The Theory of Domestic Content Protection and Content Preference," Quarterly Journal of Economics, vol. 96 (November 1981), pp. 583-603. 
mental in inducing Japanese auto manufacturers to export more of their large and more expensive models. ${ }^{10}$ In principle, greater proportions of high-quality imports under protectionist measures could displace a greater value of domestic production than would be displaced under free trade. ${ }^{11}$

Of course, proponents of protection have a narrower objective, that of assisting workers in particular industries. Quotas are, however, an expensive means of saving jobs because they raise prices paid by consumers on both the imported goods subject to quotas and the domestically produced goods with which they compete. Gary Hufbauer and Howard Rosen find that the cost to consumers per job saved by protection are "usually in the range of $\$ 20,000$ to $\$ 100,000$ per year and often exceed $\$ 150,000$."' 12 Murray Weidenbaum and Michael Munger also find that the annual costs for each job saved by protection have been high: $\$ 74,155$ because of quotas on television receivers, $\$ 77,714$ from tariffs and quotas on footwear, $\$ 85,272$ from tariffs and quotas on carbon steel, and $\$ 110,000$ on account of the "trigger price" system on steel. ${ }^{13}$

As high as they are, these estimates are likely to understate the costs of using protection to preserve jobs. Proponents of protection are generally more interested in saving the particular jobs of those currently employed in an industry than in preserving industrywide employment in the aggregate. But specific jobs can rarely be saved. Protectionists believe that by diverting demand to domestic firms, quotas will improve the firms' profitability and prevent layoffs. But quotas may actually

10. Robert C. Feenstra, “End Voluntary Trade Quotas," New York Times, December 26, 1984.

11. See, for example, Robert E. Baldwin, "The Changing Nature of U.S. Trade Policy since World War II," in Robert E. Baldwin and Anne O. Krueger, eds., The Structure and Evolution of Recent U.S. Trade Policy (University of Chicago Press, 1984), pp. 9-12; Rodney E. Falvey, "The Composition of Trade within Import-Restricted Product Categories," Journal of Political Economy, vol. 87 (October 1979), pp. 1105-14; and Gary J. Santoni and T. Norman Van Cott, "Import Quotas: The Quality Adjustment Problem,", Southern Economic Journal, vol. 46 (April 1980), pp. 1205-27.

12. Gary Clyde Hufbauer and Howard F. Rosen, Trade Policy for Troubled Industries (Washington, D.C.: Institute for International Economics, 1986), p. 5. For a set of comprehensive estimates, see Gary Clyde Hufbauer, Diane T.Berliner, and Kimberly Ann Elliot, Trade Protection in the United States: 31 Case Studies (Washington, D.C.: Institute for International Economics, 1986).

13. Murray Weidenbaum and Michael Munger, "Protection at Any Price?' Regulation, vol. 7 (July-August 1983), p. 15. 
increase job loss and dislocation by raising investment, encouraging domestic firms to relocate, attracting foreign firms, and strengthening domestic monopolies in product and labor markets.

If protection stimulates investment and the substitution of capital for labor, more jobs could be lost than are saved. ${ }^{14}$ And even in cases where protection has allegedly been effective in raising employment, industry relocation has increased worker dislocation. Of sixteen American industries studied by Robert Lawrence and Paula DeMasi that have received protection under the escape clause-which provides temporary protection from imports when the industry can prove it is being injured by imports-only one, the bicycle industry, expanded after it was protected. ${ }^{15}$ And even in that instance, protection failed to save many of the jobs that existed when it was granted in 1955. Although overall production and employment in the bicycle industry grew after 1955, each of the three largest bicycle manufacturers closed plants and moved in the next five years. ${ }^{16}$ To the degree that protection encouraged these firms to undertake long-term expansion, it also encouraged them to reexamine their choice of location.

Saving the jobs of textile and apparel workers in New England was one reason given for the U.S. entrance into the first of several multilateral restraint agreements in 1962. Overall employment in the American textile industry did increase by about 9 percent between 1961 and 1973, a development that some have argued demonstrates the success of protection. But the aggregate data mask massive relocations to the South and West by firms seeking lower labor costs. Between 1960 and 1970 textile employment declined 34 percent in New England, while increasing 19 percent in the South. ${ }^{17}$ In 1959, the North Atlantic region in the United States was home to 30 percent of textile and 60 percent of apparel employment; by 1976, these shares had fallen to 20 and 34 percent,

14. For a demonstration in the case of textiles, see Peter Isard, "Employment Impacts of Textile Imports and Investment: A Vintage-Capital Model," American Economic Review, vol. 63 (June 1973), pp. 402-16.

15. Robert Z. Lawrence and Paula R. DeMasi, "Do Industries with a Self-Identified Loss of Comparative Advantage Ever Adjust?" in Gary C. Hufbauer and Howard F. Rosen, eds., Domestic Adjustment and International Trade (Washington, D.C.: Institute for International Economics, forthcoming).

16. See U.S. International Trade Commission, The Effectiveness of Escape Clause Relief in Promoting Adjustment to Import Competition: Investigation No. 332-115 under Section 332 of the Tariff Act of 1930, USITC Publication 1229 (March 1982), pp. 43-57.

17. U.S. Department of Commerce, Bureau of Economic Analysis, Regional Employment by Industry, 1940-1970 (Government Printing Office, 1975), pp. 2, 229, 408. 
respectively. ${ }^{18}$ Despite relocation, the problems plaguing the industry remained. The United States began the 1960s responding to pleas from Northeastern textile and apparel workers for protection; it ended the decade answering the same pleas from textile workers in the South and West. Had the new entrants in the South not been enticed into the textile industry, greater import penetration could have been accommodated with no additional dislocation. Indeed, according to the Organization for Economic Cooperation and Development (OECD), fully one-third of the U.S. clothing and textile establishments existing at the end of 1982 were created after 1976. ${ }^{19}$

Protection could increase competitive pressures and dislocation for domestically owned firms and their workers and cause a wasteful use of resources. For example, after an orderly marketing agreement limited television imports in 1977, Japanese television manufacturers invested in production facilities in the United States, thus increasing competitive pressure on the few remaining domestically owned manufacturers of television receivers. A similar pressure on U.S.-owned automobile production capacity and employment is apparent as a result of the numerous Japanese automobile manufacturers that have moved production to the United States.

By strengthening a domestic monopoly or the market power held by a few dominant producers and encouraging them to raise prices, quotas can actually cut domestic sales and employment. According to estimates by Clifford Winston and others, by inducing U.S. automobile manufacturers to raise their prices, the voluntary export restraints on Japanese automobiles actually reduced U.S. automobile employment in 1983 by $31,000 .^{20}$ Indeed, the crisis cartels used in Germany in the 1930s and, more recently, in Japan to aid depressed industries create a similar problem. Such arrangements may raise domestic prices and boost profits but actually increase dislocation for workers and suppliers. ${ }^{21}$ In the face

18. Anne O. Krueger, "Protectionist Pressures, Imports and Employment in the United States,"' Scandinavian Journal of Economics, vol. 82, no. 2 (1980), pp. 133-46.

19. OECD, The Costs and Benefits of Protection (OECD, 1985).

20. Winston and Associates, Blind Intersection? See also Robert C. Feenstra, "Voluntary Export Restraint in U.S. Autos, 1980-81: Quality, Employment, and Welfare Effects," in Baldwin and Krueger, eds., The Structure and Evolution of Recent U.S. Trade Policy, pp. 35-65.

21. See Robert Z. Lawrence, "A Depressed View of Policies for Depressed Industries," paper prepared for conference on U.S.-Canadian Trade and Investment Relations with Japan (University of Michigan, April 2-3, 1987). 
of union power in the labor market, wage levels in any industry depend on the strength of competition in the market for the final products of that industry. A quota that reduces competitive pressures from abroad will thus reduce the elasticity of demand for both final products and labor, encouraging higher union wages and reducing industrial employment. ${ }^{22}$

One might conclude from this discussion that a superior method of limiting dislocation from existing jobs is to subsidize employment directly, as several European countries have done. Yet in practice such subsidy programs may neither save jobs nor limit dislocation. Employment subsidies may inhibit dislocation when temporary shocks would otherwise cause firms to lay off workers, but if the shock turns out to be permanent, workers eventually lose their jobs anyway when government coffers run dry. Historically, such budgetary shortfalls have forced governments to remove subsidies suddenly. In the long run, therefore, jobs are not only not saved, but large numbers of workers whose jobs are no longer economically viable may suffer more dislocation than they would have if the market had operated freely. The European experience does not suggest that less adjustment is required simply because it is delayed. ${ }^{23}$

\section{RESTORING COMPETITIVENESS}

The infant industry argument is the classic case in which protection is provided to allow a new industry to grow sufficiently to become a viable international competitor. Given the developed nature of the U.S. economy, the infant industry argument is rarely invoked, but a related argument calling for industry rejuvenation is. The frequently stated objective of protection is to allow import-damaged industries a breathing period in which to restore their competitiveness. But if an industry can be profitable once it has reequipped itself, why can't it enter the capital

22. See Colin Lawrence and Robert Z. Lawrence, "Manufacturing Wage Dispersion: An End Game Interpretation,"' BPEA, 1:1985, pp. 47-106.

23. For estimates of the waste in keeping the Shelton Works, a steel firm in the United Kingdom, open too long, see Victoria Curzon Price, "Alternatives to Delayed Structural Adjustment in 'Workshop Europe,' " World Economy, vol. 3 (September 1980), pp. 20516. Once the British government determined to restore the financial viability of the firm, it had to eliminate the excess labor much more rapidly than might have occurred without initial government aid. See also Egbert Gerken, Martin Gross, and Ulrich Lachler, "The Causes and Consequences of Steel Subsidization in Germany," European Economic Review, vol. 30 (August 1986), pp. 773-804. 
market to obtain the finances to tide itself over until it is profitable? Why are private participants in the capital market unable to recognize these opportunities? The answer implicit in the industry rejuvenation rationale for special trade assistance is that there is a major failure in the capital market.

The United States, however, has the best-developed capital market in the world. It has nearly 15,000 commercial banks, over 3,000 insurance companies and pension funds, and numerous highly talented and wellcapitalized investment banking houses, let alone the largest network of stock and bond exchanges in the world. With so many potential suppliers of capital and such a highly sophisticated system of financial intermediaries to channel their funds to capital users, there is no reason why the market should systematically fail to recognize and finance industries able to compete in the international marketplace. And even if such systematic errors were occurring, there does not seem to be any evidence suggesting that government officials or lawmakers have superior forecasting ability and are unable, by releasing their own information, to convince private participants of its value.

A related argument is that quotas or tariffs permit firms to modernize and restructure by allowing them to earn higher profits. This argument too ignores the possibility that companies could borrow from capital markets. It also presumes that only the management and owners of existing firms should be responsible for undertaking new investment. On occasion, however, ridden by inferior management or by debt from previous investment errors, existing firms may be ill suited to undertake new investments. Selling assets to more creditworthy owners rather than salvaging the returns on past investments may be the appropriate method for facilitating industrywide recovery.

Significantly, even protection may fail to promote an industry that is not viable in an unprotected market. When an industry producing a standardized product loses its comparative advantage, far more than the latest technology will be required to regain competitiveness. In fact, the passage of time may accentuate the cost differential between domestic and foreign firms. Given the rapid international diffusion of technology, foreign competitors can also modernize. In such cases the availability of protection as an option may divert the industry's attention away from eliminating unprofitable operations and toward efforts to maintain protective barriers. 
Comparative rather than absolute advantage will determine the ultimate success of an industry in global competition. Proponents of protection for a particular industry may find it difficult to appreciate the importance of comparative advantage. Indeed, the preamble to the textile quota bill passed by the House of Representatives last year notes that increases in textile imports and import penetration in the U.S. market have occurred despite productivity increases in the past ten years that have surpassed increases in the rest of the economy. ${ }^{24}$ But the textile and apparel industries could have suffered an erosion in comparative advantage despite above-average productivity.

To be sure, some industries have made strategic errors that in time could be corrected. For example, the two oil shocks in the 1970s dramatically shifted the structure of demand for automobiles in the United States toward small cars, a shift that American manufacturers were not able to anticipate. Yet even in the case of correctable errors, the impact of protection on modernization depends on the form of that modernization and whether protection is viewed as permanent or temporary. Import quotas to improve competitiveness may well prove counterproductive. The voluntary export restraints on Japanese automobiles increased the profits not only of American auto manufacturers but also of their major foreign competitors. ${ }^{25}$ While U.S. firms may have been using the revenue from quotas to modernize, their competitors may have been doing likewise, perpetuating if not widening their cost advantage over American producers. Similarly, according to the OECD, U.S. steel restraints raised foreign profits as much as those of U.S. producers. In addition, long-term protection encourages unions to seek higher wages, which if granted can further undermine the competitiveness of the domestic industry. Various forms of protection accorded to the American steel industry during the 1970s appear to have had this effect. ${ }^{26}$

Some lawmakers have recently suggested that recipients of protection should commit themselves to adjustment strategies agreed upon jointly by representatives of management, labor, and government. Proponents

24. H.R. 1562 noted that productivity in textile mills increased between 1975 and 1985 at the average annual rate of 4.2 percent, as compared with the 1.9 percent growth of productivity in all manufacturing in the same period.

25. Elias Dinopoulos and Mordechai E. Kreinen, "Effects of the U.S.-Japan Auto VER on European Prices and U.S. Welfare"' (Michigan State University, January 1987).

26. Lawrence and Lawrence, "Manufacturing Wage Dispersion," pp. 75-76. 
argue that protection would save jobs while the adjustment requirements would help restore the international competitiveness of import-damaged industries. However, conditioning aid on acceptance of adjustment mechanisms has pitfalls that are not well appreciated in much of the U.S. policy discussion. ${ }^{27}$

Setting conditions as a quid pro quo for protection presumes that the government-either alone or together with business and labor representatives-can better decide what form adjustment should take and how to accomplish it than can affected firms and their capital markets. While advocates of this approach believe it will result in a speedier transition to free trade, we are skeptical. In fact, given the political reluctance to abandon industries in trouble, it is likely that mandated adjustment would be biased towards requiring substantial reinvestment in importdamaged industries in the hope that new capital and modernized plants would restore competitiveness. While individual firms in depressed industries may survive by modernization, it is unlikely that mandating investment by all, as Congress did in the case of the steel industry in 1984, will mean that all will survive. On the contrary, such policies are more likely to perpetuate excess capacity and induce wasteful investment.

In cases where agreements call for the retirement of capacity, the conditionality approach produces another danger-cartelization. If import relief is to be conditional on specified actions by the industry, firms have strong incentives to arrive at tacit, or even explicit, understandings to coordinate their behavior. Indeed, it is no coincidence that such policies are frequently associated with the formation of cartels in Japan. While it may be necessary for an industry to restructure through mergers, these are better achieved in the open market than through collusion between industry participants. As we argue later, when industries are clearly subject to competitive pressures from imports, mergers should be allowed, but the government should not shift its stance from trustbusting to trust-building. Moreover, as Japanese and European experience makes clear, firms that make painful capacity retirement decisions to raise prices are likely to seek measures to prevent new entry by free riders from undermining their cartel arrangements. With effective car-

27. For a detailed discussion of the problems, see Robert Z. Lawrence and Robert E. Litan, Saving Free Trade (Brookings, 1986); and Robert Lawrence, "A Depressed View of Policies for Depressed Industries." 
telization, consumer costs of protection would be much higher than those estimates reported earlier. When cartelization is not feasible, as in the case of textiles, such dangers are lower. But where industries are competitive, conditionality agreements are impractical for another reason: the difficulties of monitoring compliance in sectors with thousands of firms and pluralistic labor-management relations.

\section{PRESERVING ESSENTIAL INDUSTRIES}

By harming certain key domestic industries, trade can allegedly impair the national defense. But trade protection is a highly inefficient means of preserving production capacity of an industry deemed essential to national security. It would be far less costly to pay for the necessary capacity and stockpiles of products directly out of the federal budget.

Others have justified special government treatment by asserting a need to protect and support certain "basic" industries, such as steel, considered to be essential to the performance of other industries. ${ }^{28}$ The government, they argue, must shelter input-producing industries from import competition, or even subsidize them, to prevent the American industries relying on them from becoming vulnerable to price hikes or supply disruptions.

The first problem with this line of argument is that it applies only, if at all, to products for which international competition is weak-as it was for crude oil in the 1970s when the OPEC cartel had effective control over world oil prices. When competition among foreign producers is brisk, American purchasers have no reason to be concerned that domestic suppliers may be driven out of business or forced to shrink capacity because of predatory practices or more efficient operations of foreign producers. Indeed, American business will suffer if government misguidedly imposes a tariff or quota on imports of basic products because such measures would only raise prices and thereby reduce or destroy any competitive advantage American manufacturers of finished goods might enjoy in the international marketplace.

A second flaw in the basic industries rationale is that there is no clear way to distinguish between what is basic and what is not. Many industries

28. Eleanor M. Hadley, "The Secret of Japan's Success," Challenge, vol. 26 (MayJune 1983), pp. 4-10; Ira C. Magaziner and Robert B. Reich, Minding America's Business: The Decline and Rise of the American Economy (Harcourt Brace Jovanovich, 1982). 
produce inputs for other industries: lumber for wood products, copper for finished metal products, and cotton for textiles. Why should only one or two of these input-producing industries receive protection from imports?

\section{A Pragmatic Policy for Preserving Open Trade}

Over the past two years, there has been a substantial decline in the U.S. dollar. With time, this fall will improve the trade balance and alleviate many of the current protectionist pressures. Nonetheless, the dollar's fall is not a panacea. Its decline will reduce the purchasing power of U.S. consumers. The only way the nation can offset the real income loss that accompanies the decline in the value of the dollar is to raise productivity levels. A discussion of policy measures to accomplish that objective is beyond the scope of this article, but it is encouraging that both political parties are concentrating on the issue and considering policies to bolster educational and retraining efforts as well as research and development spending. In addition, the dollar's fall should be accompanied by shifts in both U.S. spending and trade policies. An effective policy must be capable not only of reversing national overspending without damaging investment, but also of holding protectionist pressures at bay during the potentially difficult transition to smaller trade deficits.

\section{SHIFTING NATIONAL SPENDING PATTERNS}

As the trade deficit declines, the imbalance between national spending and production can theoretically be narrowed either by reducing private investment, raising private saving, or reducing the government deficit, or by some combination of the three. All are neither equally desirable nor equally feasible.

The least desirable option is reducing private investment. At a time when U.S. firms are facing severe competitive pressures, America must, if anything, increase rather than lower its rate of investment. Yet in the absence of higher domestic saving, the decline in the trade balance and in the associated net inflow of foreign capital could raise real U.S. interest rates and crowd out domestic investment. 
A second course-increasing private saving —is far more desirable, but not readily susceptible to changes in government policy. After decades of empirical studies, it remains unclear whether saving patterns are sensitive to changes in interest rates and, if so, in what direction. The increased private saving advertised as one of the main benefits of the 1981 "supply-side" cut in personal income tax rates has failed to materialize. Net personal savings stood at 7.5 percent of personal disposable income in 1981. By 1986, the personal saving rate had fallen to 3.8 percent-the lowest level since 1949.

The third option-substantial reduction of the government deficit, and in particular, the federal budget deficit-is by far the most feasible, if politically difficult. Although macroeconomists may disagree about the desirability of completely eliminating the federal deficit, there is a broad consensus in the policymaking community that the deficit must eventually be brought down from its current $\$ 150-\$ 200$ billion range to something on the order of $\$ 50$ billion. There is also consensus that deficit reduction should take place gradually and, if the need arises, be temporarily halted or even reversed if the economy slides into recession.

\section{RESISTING PROTECTION}

Reversing overall trade patterns will not only be politically difficult, but also will take time. In the interim, during which the trade deficit may come down but still hover around $\$ 100$ billion, there will be continuing political pressure to embrace protectionist measures. Indeed, despite its free trade convictions, the Reagan administration has resorted increasingly to protection, and in the worst way possible-by using quotas and sanctioning the creation of cartels.

A major reason why even an administration as philosophically committed to free trade as the present one has found it necessary to cave in to pressures for protection is that the two safety valves in our current trade regime for relieving protectionist pressures are imperfect.

The first, the so-called escape clause, allows domestic industries to receive temporary protection from imports when they can prove to the U.S. International Trade Commission (ITC) that imports threaten or cause them serious economic injury. Although the escape clause has been reasonably effective in screening out the most unworthy domestic industries and depriving them of temporary assistance-roughly 40 
percent of all applicants since the law was last revised in 1974 have been denied relief by the ITC-it nevertheless has a fatal flaw. An industry can win its case before the ITC but still be denied relief by the president. The effect is to encourage the industry to run to Congress for permanent protection, as the domestic shoe and copper industries have done in the past two years. Another problem is that the law allows the president to provide temporary import relief in the form of quotas as well as tariffs. And while tariffs distort trade flows somewhat, they are less disruptive than quotas. They also, unlike quotas, raise revenue for the government.

The second safety valve, trade adjustment assistance (TAA) for firms, workers, and communities adversely affected by import competition, has been rendered increasingly ineffective because of severe funding cuts over the past five years. Moreover, even in its heyday, TAA did little more than delay adjustment, particularly by displaced workers, who were merely given extended unemployment compensation payments without being positively encouraged to find work elsewhere.

In our study, Saving Free Trade, we outline several changes in both the escape clause and the TAA program that would make them more useful. ${ }^{29}$ First, the escape clause would be more cost effective if declining tariffs were the sole form of temporary import relief. All existing quotas and other quantitative restrictions should be converted to their tariff equivalents by auction; that is, all rights to import products within quota ceilings should be sold to the highest bidders. Tariff rates should then be scheduled to decline over time. The revenue raised by these tariffs should be earmarked for assisting workers adversely affected by imports.

Second, we recommend that an affirmative injury finding by the International Trade Commission automatically trigger two different types of relief. First, mergers of firms in beleaguered industries not protected by quotas would be assessed under liberalized standards, as recently recommended by the Reagan administration. If an industry is judged by the ITC to be seriously damaged by imports, then there is little worry that mergers will lead to imperfect competition. Second, trade adjustment assistance, primarily in the form of insurance against loss of wages, would automatically be extended to displaced workers. By

29. See Robert Z. Lawrence and Robert E. Litan, Saving Free Trade, chap. 5, for more details. For a similar view, see Gary Clyde Hufbauer and Howard F. Rosen, Trade Policy for Troubled Industries. 
compensating workers for some proportion of any reduction in wages in new jobs, TAA would encourage workers to find and accept new employment, thus hastening adjustment. The proportion of the loss compensated could vary with the age of the worker and his or her seniority in the previous job. Extended unemployment compensation would be provided to workers residing in regions where the unemployment rate significantly exceeds the national average. Relocation allowances and assistance for retraining would also be available. Federal loans for retraining would carry repayment obligations tied to future earnings; repayments would be collected automatically through the income tax system.

Our proposed program of trade adjustment assistance could be readily financed for at least a decade by converting existing quotas into declining tariffs. As a result, there would be no financial pressures to impose new tariffs to fund the assistance program, although the president would still have authority to grant tariff remedies to domestic industries proving to the ITC that they merit relief.

Finally, we propose a system of insurance by which municipalities, counties, and states can ease the pain of economic dislocation. Participating governmental entities would pay an insurance premium, much like the premiums firms currently pay for unemployment compensation, for a policy that would compensate for losses in the tax base caused by plant closures or significant layoffs.

The United States will not be able to reverse its trade balance until national spending patterns change. But in the meantime, we must do a far better job in easing the difficult dislocations that the persistent trade imbalance has caused. 